\title{
ANIMAL EXPERIMENTS OF MYCOBACTERIUM LEPRAE
}

\author{
Yoh Nakagawa and Masahiro Nakamura \\ Department of Bacteriology, Kurume University \\ School of Medicine, Kurume-shi.
}

The effects of various following experimental methods to the affections of leprosy on mice and developing chick embryos have been tested.

1. Subcutaneous or intraperitoneal injections of glandular mucin and Ota's solution containing trypan blue, diatom, and Kali Jodi, into mice before or after the inoculation of Myc.

Leprae.

2. Intraperitoneal injection of cobra venom before the inoculation of lepra bacilli.

3. Intracerebral inoculation of Myc. leprae into suckling or very young mice.

4. Inoculation of Myc. leprae into yolk sacs of developing chick embryos.

No results which promoted the propagation of lepra bacilli was obtained in all experiments.

\section{人癩の動物実験に関する研究}

\author{
久留米大学医学部細菌学教室 中 川 洋, 中 村 昌 弘 \\ (昭和 29 年 6 月 8 日受稿)
}

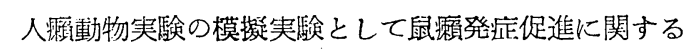
研究(1)(2)妾行いつつあるが，一方には直接人㴼菌の動物 按種実験を試みつつむるので，今回はその $2 ・ 3$ につい て報告したいと思ら。今回行つた人瀬菌の動物実鍳は先

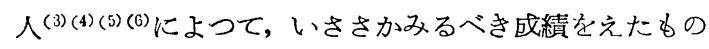
の方法の追試とこれに多少の創意を加味したもの並に絬 核菌の坮養手段として用いられる畉黄队坮養方法 ${ }^{(7)(8)}$ 等 の諸方法を行つたものである。

\section{実 験 方 法}

供試材料：恵楓園より分与をうけた人瀨結節の生塩水 による10〜20倍稀粎液を用いた。

俱試動物：幼若道に成熟マウスを用いたにはかに瞬化 5 日の有精慆卵を用いた。供試動物数は原則として各群 5 例とした。

接種部位：マウスでは右膝べキ部皮下，榎腔内，脳内 及び辑丸内によつた。睜化鶏畉では卵黄内方法によつ た。

\section{試用薬物:}

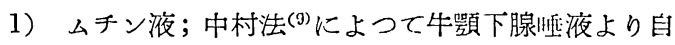
家作製した2〜4\%溶液を用いた。

2） 10,000 倍のコブラ毒液。

3）太田液(10) ; トリパソ青, 硅藻土及び沃度加里各 $0.1 \mathrm{gr}$ 宛を生塩水 $100 \mathrm{cc}$ に添加して充分䇠有したもの。
観察：睬化鷄畉群に招いては菌接種後10及び14日に直 接塗抹祭本並に Brueck 等( ${ }^{(8)}$ による集菌法によつて標本 を作製した。その他の動物実験に颃いては菌接種後 3 〜 5 力月後屠殺し, まず接種局所の肉眼的観察次に剖検に よる該部並に各種淋巴腺内脦に打ける菌の存在の有然, 更に病理組織学的観察を行つた。な颃, 途中で整死した ものについてはてれを成績より除外した。

\section{実 験 成 綪}

1）ムチン及び太田液を用いての実験

本実験に打いては人碩乳剤に $2 \%$ \%チン液を等量に加 へ腹腔内に接樌した郡，乙れに後処䈯として接種翌日よ り 15 日毎に 4\%ムチン液を腹浐内に $0.2 \mathrm{cc}$ 注射する群, 30 日每に接種する群，2\%ムチン液に等量の太田液を加

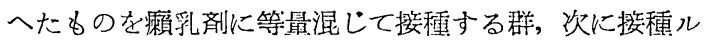
ートを右滕べキ部皮下としたもので, 頙乳剤に $2 \%$ \% ンを添加した群，この接種の前日に $4 \%$ チン $0.2 \mathrm{cc}$ を 腹腔に投与前処置した群，この群に後処置として4\%ム チンを15日毎に腹腔内に与へた群，30日毎に与へた群， 前処置としてムチンの代りに太田液を右膝べキ部皮下に むたつた群。

これに後処置を行つた 2 群, 対照として䠭乳のみを腹 腣内，右㯲べキ部皮下に接種した 2 郡，合計 13 群を行ひ 
3 カ月後にこれら動物を屠殺剖検し，所見を観察した。 その実験方法並に成績は第 1 表として揭げる。

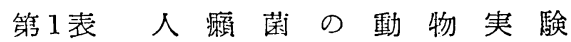

\begin{tabular}{|c|c|c|c|c|c|c|c|c|c|c|}
\hline \multirow{3}{*}{$\begin{array}{c}\text { 群 } \\
\\
1\end{array}$} & 姜種 & 材 料 & \multirow{2}{*}{$\begin{array}{l}\text { 㜔種 } \\
\text { 部位 }\end{array}$} & \multicolumn{2}{|c|}{ 揬種前日の処置 } & \multirow{2}{*}{$\begin{array}{c}\text { 後 } \\
\text { 投 与 液 }\end{array}$} & \multicolumn{2}{|l|}{ 処置 } & \multirow{2}{*}{$\left|\begin{array}{|cc}\text { 実 } & \text { 匼 } \\
\text { マウ } \\
\text { 頭 } \\
\text { 数 }\end{array}\right|$} & \multirow{2}{*}{ 所見 } \\
\hline & 菌 乳 郕 & 添 加 物 & & 投与液 & 部位 & & 投与間隔 & 部位. & & \\
\hline & $\mid \begin{array}{l}\text { 愁楓園第十五号 } \\
\text { 結節の㙏水 } \\
10 \times \text { 液 } 0.2 \mathrm{cc}\end{array}$ & $2 \%$ $\% ン$ & 腹䧑内 & - & - & - & - & - & 5 & - \\
\hline 2 & " & " & " & - & - & $\begin{array}{l}4 \% \text { チ元ン } \\
0.2 \mathrm{cc}\end{array}$ & 15日每 & 腹腔内 & 5 & - \\
\hline 3 & " & " & " & - & - & " & 30日每 & " & 5 & - \\
\hline 4 & " & $2 \%$ 2 チント太田液 & " & - & - & - & - & - & 2 & - \\
\hline 5 & " & $2 \%$ \%ン & \begin{tabular}{|} 
右銅べ \\
キ部皮 \\
下
\end{tabular} & - & - & - & - & - & 3 & - \\
\hline 6 & " & " & " & $\begin{array}{l}4 \% \text { \%チン } \\
0.2 \mathrm{cc}\end{array}$ & 腹腔内 & - & - & - & 5 & - \\
\hline 7 & " & " & " & " & " & $\begin{array}{l}4 \% \text { \%ムチン } \\
0.2 \mathrm{cc}\end{array}$ & 15日毎: & 腹脱内 & 5 & - \\
\hline 8 & $"$ & " & " & " & " & " & 30 日每: & " & 3 & - \\
\hline 9 & " & " & " & $\begin{array}{l}\text { 太田液 } \\
0.2 \mathrm{cc}\end{array}$ & $\begin{array}{l}\text { 右䅈べ } \\
\text { キ部 }\end{array}$ & - & - & - & 5 & - \\
\hline 10 & " & " & " & " & " & $\begin{array}{l}2 \% \Delta チ ン+ \\
\text { 太田液 } 0.2 \mathrm{cc}\end{array}$ & 15 日毎: & $\begin{array}{l}\text { 右㭗べ } \\
\text { キ部 }\end{array}$ & 5 & - \\
\hline 11 & " & " & " & " & " & " & 30日每 & " & 3 & - \\
\hline 12 & " & " & 腹腔内约 & - & - & - & - & - & 2 & - \\
\hline 13 & " & " & 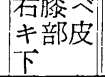 & - & - & - & - & - & 2 & - \\
\hline
\end{tabular}

ネられた成績はすぺて陰性でまつて，抗酸菌の増侃像 も㿎細胞の出現も認められなかつた。

2）コブラ毒前処置による実験

1 万倍コブラ毒 $0.2 \mathrm{ec}$ を瀨菌接種 24 時間前に動物の腹 腔内に注射する群, コブラ毒の $0.1 \mathrm{cc}$ を注射する群。此 の両群共翌日人瀨菌浮游液を皮下, 腹院内, 翠丸内及び 脳内に接種する。次にコブラ毒の $0.1 \mathrm{cc}$ を前処置後, 㕵

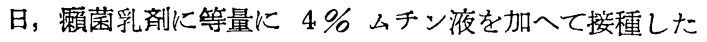
群, 前処置のコブラ䓯を $0.05 \mathrm{cc}$ にした群，コブラ毒を $0.2 \mathrm{cc}$ にした群，

合計 5 群について行つた。本実験に颃いても 3 カ月後 に屠殺剖険し所見を観祭した。その成綪は第 2 表に揭げ
る。

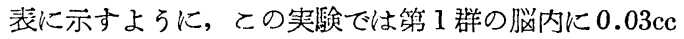
人瀨乳剂が接種された 3 例のらちの 1 例の肝淢に抗酸菌 の群の集合が認められた。しかしこの所見は癩細胞の出 現を伴つていないし，抗酸菌の菌形，配列からして，䅋 菌とは揕しく異つた抗酸菌であつた。但し, 次代への植 つぎ，抗酸菌用培地への培養を行つていない。なた第 3 群の翌丸内接種群の 4 例中 1 例に右哇丸内に抗酸菌の中 等度の集団を 1 カ所に認めた例に遭遇した。しかし，と れも瀨細胞の浸潤を伴つていなかつたため, 霜菌の增殖 したのではない感を哚くしたが，累代接種及び抗酸菌用 培地への培養を行つていないので断定は憚り度い。 
第 2 表 コブラ毒前処置による人癩菌の動物接種実験

\begin{tabular}{|c|c|c|c|c|c|c|}
\hline \multirow{2}{*}{ 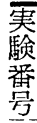 } & 実 & 験 & 法 & & |成熟 & \multirow{2}{*}{ 実臨成績 } \\
\hline & 前処置 & 接霾材料 & $\begin{array}{l}\text { 接種 } \\
\text { 部位 }\end{array}$ & \begin{tabular}{|c|} 
接種 \\
量
\end{tabular} & 頭 & \\
\hline \multirow{4}{*}{ I } & \multirow{4}{*}{ 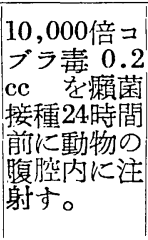 } & \multirow{4}{*}{ 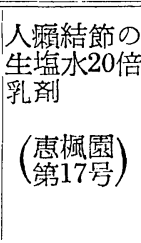 } & 皮下 & $\begin{array}{r}0.2 \\
\mathrm{cc}\end{array}$ & 3 & \multirow{3}{*}{$(-)$} \\
\hline & & & 腹腔内 & 0.2 & 3 & \\
\hline & & & 粱丸内 & 0.05 & 3 & \\
\hline & & & 脸内 & 0.03 & 3 & $\begin{array}{c}\text { 肝に抗酸菌 } \\
\text { の集合为り }\end{array}$ \\
\hline \multirow{4}{*}{ II } & \multirow{4}{*}{$\begin{array}{l}10,000 \text { 倍ュ } \\
\text { ブラ毒 } 0.1 \\
\mathrm{cc} \text { を同上 } \\
\text { I処置す。 }\end{array}$} & \multirow{4}{*}{$\begin{array}{c}\left.\text { 阔 } \begin{array}{c}\text { 上 } \\
(\text { 惠楓園 } \\
\text { 第18奇 }\end{array}\right)\end{array}$} & 皮下 & 0.2 & 5 & \multirow{4}{*}{$(-)$} \\
\hline & & & 腹䧑内 & 0.2 & 5 & \\
\hline & & & 啐丸内 & 0.05 & 3 & \\
\hline & & & 脳内 & 0.03 & 2 & \\
\hline \multirow{3}{*}{ III } & \multirow{3}{*}{ 同上 } & \multirow{3}{*}{ 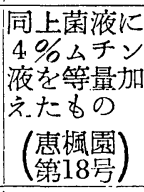 } & 腹腔内 & 0.2 & 4. & $(-)$ \\
\hline & & & 睪丸内仙 & 0.05 & 4 & $\begin{array}{l}\text { 右罜丸内に抗 } \\
\text { 酸菌中等度 }\end{array}$ \\
\hline & & & 脳内 & 0.03 & 2 & $(-)$ \\
\hline \multirow{4}{*}{\multicolumn{2}{|c|}{$\begin{array}{l}10,000 \text { 倍 } \\
\text { IVラ毒0.05 } \\
\text { IV 処置す。 }\end{array}$}} & \multirow{4}{*}{ 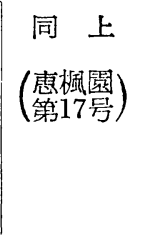 } & 皮下 & 0.2 & 3 & \multirow{4}{*}{$(-)$} \\
\hline & & & 腹胎内 & 0.2 & 3 & \\
\hline & & & 睪丸内 & 0.05 & 3 & \\
\hline & & & 脳 内 & 0.03 & 3 & \\
\hline & \multirow{4}{*}{$\begin{array}{l}10,000 \text { 倍コ } \\
\text { ブラ毒 } 0.2 \\
\text { cc を同上 } \\
\text { 処置す。 }\end{array}$} & \multirow{4}{*}{ 同上 } & 皮下 & 0.2 & 5 & \multirow{4}{*}{$(-)$} \\
\hline & & & 腹腔内 & 0.2 & 5 & \\
\hline & & & 筧丸内内 & 0.05 & 4 & \\
\hline & & & 豚 内 & 0.03 & 4 & \\
\hline
\end{tabular}

3）幼若動物を用いての実験

供試動物は生後 5,7 及び 12 日のものと対照として成 熟マウスを用いた。接種材料は人瀬材料の 20 倍生塩水乳 版そのもの及びこれに等量の $2 \%$ \%ン液を加へたもの とし，対照には加熱死菌を用いた。接種ルートは兴内に 行つた。接種量は $0.02 \sim 0.03 \mathrm{cc}$ である。その成樍は第 3 表に示す。剖険は 2 カ月後に行つた。
第 3 表 幼若動物を用いての人簀動物実験

\begin{tabular}{|c|c|c|c|c|}
\hline \multirow{2}{*}{$\begin{array}{c}\text { 零 } \\
\text { 験 } \\
\text { 䎹 } \\
\end{array}$} & 実験方法： 冈ウスの脳 & \multicolumn{2}{|c|}{ 供試動物 } & \multirow{2}{*}{ 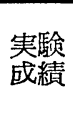 } \\
\hline & 接 種 材 料 & 年令 & 頭数 & \\
\hline \multirow{2}{*}{ I } & 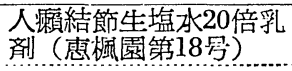 & 生後 5 日 & 7 & \multirow{2}{*}{$(-)$} \\
\hline & $2 \%$ $\%$ チン同上乳浏 & " & 8 & \\
\hline \multirow{2}{*}{ II } & " & 生後 7 日 & 3 & \multirow{2}{*}{$(-)$} \\
\hline & " & " & 3 & \\
\hline \multirow{2}{*}{ III } & " & 生後12日 & 5 & \multirow{2}{*}{$(-)$} \\
\hline & " & " & 5 & \\
\hline \multirow{2}{*}{ IV } & " & 成熟 & 4 & \multirow{2}{*}{$(-)$} \\
\hline & " & " & 4 & \\
\hline \multirow{2}{*}{ (対照) } & 加 慾 死 菌 & 生後12日 & 5 & \multirow{2}{*}{$(-)$} \\
\hline & 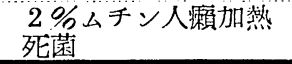 & " & 5 & \\
\hline
\end{tabular}

実匬成績はすべて陰性で，菌形すら認めえ.なかつた。

4.) 卵黄内接種実験

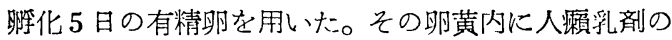
$0.2 \sim 0.5 \mathrm{cc}$ を無菌的に接種して，10日間培養ののち，そ れら畉黄のの直接塗抹祭本並儿集菌法を用いて祭本を作 製した。その成績は第4表に掲げる。

第 4. 表 入瀨菌の卵黄内坮養実験

\begin{tabular}{|c|c|c|c|c|c|}
\hline \multirow{2}{*}{ 有精卵 } & \multirow{2}{*}{\multicolumn{2}{|c|}{ 群 }} & \multicolumn{3}{|c|}{ 実瀭方法亚に成績 } \\
\hline & & & 供試畉数 & 坮養日数 & 成 績 \\
\hline \multirow{4}{*}{ 睜化 5 日卵 } & \multirow{2}{*}{ I } & 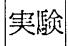 & 5 & 10 & $(-) *$ \\
\hline & & 対琞 & 2 & 10 & $(-)$ \\
\hline & \multirow{2}{*}{ III } & 実験 & 5 & 14 & (一) [雑菌2] \\
\hline & & 対照 & 2 & 14 & $(-)$ \\
\hline
\end{tabular}

* 卵黄内のみに菌数コ, 但し增列像なし。

成樍は第 1 群の実験畉中の 1 コに畈黄内の夕に散在性 の菌数コを認めたが，増㪴像はなかつた。その他では集 菌法を用いても菌形をみとめえなかつた。

\section{総括並に考按}

人霜菌の動物実験については枚挙にいとまない程の研 究が行はれているが現在までみるべき成績があげられて いない。人触菌の他種動物への移植実験に括いても人瀨 菌側の病原性の増強による訊みと被接種動物側の感受性 
の上昇による試みとがある。

今回の実験に扔いては主として後者の点について 2.3 の試みを行つた。近来, この方面の研究にはウイルスの 実験動物への適応実験として，レントゲン線照射，コー チン゙ンの投与, ムチンの前処置等がなされている。今回

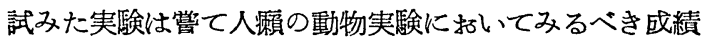
をあげたといら方法のほか炕，ウイルスの方面に用いら れた方法も加へて行つた。

ムチンの前処置についてはウイルスの研究の外にも, H. P. Lambert 等(11) の感染増強の実験がある。ムチン の前処置は明かに動物の病原微生物に対する正常抵抗力 の低下を来するのらしく，感染が容易になると云われて いる。

今回はムチンの前処置並に後処置に更に太田教授 ${ }^{(10)}$ が人瀨菌の家嵊への接種に試用したトリパン青硅藻土沃 度カリ混合液による処置を併用したが，予想の結果はえ られなかつた。

次にてれも被検動物側の抵抗力低下を来すと考へられ るコブラ毒前処置を高木 ${ }^{(3)}$ の方法に做つたものに更にム チンをも作用さして実験を行つたが，乙の場合も成績は 陰性に終始した。高木等の実験を考察すると，供試動物 多数の中に，認められるべき成績をえたものは数例に過 ぎなかつたととからして，蛇毒の前処置の外に不明の因 子が人瀨菌の増殖に寄与したものと考へられるために， 今回の実鋻も更に多数の動物を用らることによつて，何 らかの手がかりがえられるかもしれない希望がないでも ない。ととに他の実験では抗酸菌の存在さへる認められ なかつたのに，乙の実験群では人顬菌とは今のところ考 へてはいないが，先ず抗酸性菌の集団を少数例に認めた ことでも，今後再検討の要める実験と考へている。

次に幼若マウスへの接種実験はウイルス学の領域に慣 用されている方法でもめりるし他種動物に人籟に対す る正常抗体が産生されるならば，生後間もなくの時期で 正常抗体の産生される以前に人霣菌を接種したならば或
は感染を怙とすのではないかとの考へのるとと霜菌を全 く細胞寄生性の病原体と想定して直ちにウイルスの特性 と共通に考へるアイデアのもととにマウスの脳内接種を 試みたのでもるが，とれる全く予想に反して認むべき結 果をえなかつた。

最後に卵黄内接種をとれるウイルスの特性と同時に結 核菌のカテゴリーに人瀨菌を想定して行つたが，この場 合も人㹕菌は両者に全く属しない態度をとつた。

\section{結論}

マウスを用いて自家牛頕下腺ムチンの前処置並儿後処 置, 太田液の前処置並に後処置, 更にこれら 処置の 併 用, 及びュブラ書の前処置, 幼若マウス脳内接種队び有 精畉黄内接種等の方法を利用して人躈菌の動物実験を行 つたが，認むべき成績は六られなかつた。

\section{文献}

1）中村・神田・新宮：レプラ，22（2）, 93, 昭28. 3 月

2）中村・新宮：レプラ，22（2），97，昭28.3月

3）高木・福島・三井：レプラ，6 (1)，113，昭 10 . 1月

4) 高木: 実験医学雑誌, 19 (10)，1494, 昭10.10月

5） 戸田：レプラ，12（1)，1，昭16，1月

6）小河：レプラ，18（4），93，昭24，11月

7）占部・中川: 東京医事新誌, $3126 \%, 717$, 昭 14 . 3 月

8) J. W. Brueck, G. J. Buddingh : P. S. E. B. M, 80 (4) $, 589,1952.8$

9）中村 - 遠藤：日本医事新報，1279, 昭 23.10 月

10）太田・日戸・中村：東京医势新誌，3147, 昭14.

11) H. P. Lambert, H. Smith \& J. : J. Infect., Dis., 93 ( 1) $93,1953$. 